Polishchuk (science editors); I. Pokarzhevska (artistic design). Kyiv: Abris [in Ukrainian].

27. Florenskiy A. (1995). Iconostasis. Moscow [in Russian].

28. Florovskiy G. (1933). Eastern fathers V - VIII centuries. Paris, (reprint: Moscow, 1992. p. 249) [in Russian].

29. Ouspensky L., Lossky V. (1982). The Meaning of Icons [trans. G. E. H. Palmer and E. Kadloubovsky]. New

York: St. Vladimir's Seminary Press [in English].

30. Ouspensky L. (1992). Theology of the Icon. Vol. 1-2. New York: St. Vladimir's Seminary Press [in English].

31. St. John of Damascus. (1997). On the Divine Images: Three Apologies Against Those, Who Attack the Divine Images [David Anderson, Translator; English and Ancient Greek Edition]. New York: St. Vladimir's Seminary Press [in English].

32. Rice, D. Talbot. (1968). Byzantine Painting: the Last Phase. New York: Dial Press [in English].

33. The Glory of Byzantium. Art and Culture of the Middle Era. A.D. 843-1261. (1997). New York: The Metropolitan Museum; Byzantium. Faith and Power. 1261-1557. (2004). New York: The Metropolitan Museum [in English].

34. Theodore The Studite. (1981). On the holy icons. [Catharine P. Roth, Translator]. New York: St. Vladimir's Seminary Press [in English].

35. Tradigo A. (2005). Icons. Masterpieces of the Eastern Church. Picture dictionary of art. Berlin [in German].

Стаття надійшла до редакції 23.10.2019 p. Прийнято до публікації 21.11.2019 p.

UDC 159.928.23:78.07

Kapliyenko-Iliuk Yuliya

Ph.D. in Arts, associate professor, doctoral student of the Odessa National

A. V. Nezhdanova Academy of Music

ORCID 0000-0002-6114-9680

yuliyakaplienko@gmail.com

\title{
PSYCHOLOGICAL PRECONDITIONS OF MUSICAL CREATIVITY
}

The purpose of the article is to analyze the psychological foundations of creative thinking as a prerequisite for musical creativity. The methodology is determined by the works in the field of psychology, which focus on the psychology of creativity, the problems of musical talent and creative thinking, encyclopedic resources, which reveal the essence of the notion of creativity, and musicology studies devoted to the issues of the creative process and musical activity. Scientific novelty consists of scientific comprehension of preconditions of musical creativity; in systematizing the psychological foundations of the creative process; in finding out the principles of creative thinking. Conclusions. Musical creativity is a complex process of artistic and creative thinking, which involves the creation of new spiritually valuable works. The psychological preconditions of musical creativity, such as talent, skill, intuition, creativity, and improvisation, are connected, first of all, with the psychic and mental development of the individual. However, the role of learning, acquiring skills and experience, the formation of imagination and accumulation of impressions is of great importance, because the process of creativity is associated with mental operations on the material primarily through conscious mechanisms. In the musical creativity there is an active and continuous correlation between the conscious and the unconscious. These two types of thinking complement each other, alternating depending on the tasks set before the composer. Creative tasks are realized with the help of creative-psychological settings, among which, the important role of emotions, intuition, reason, logic, rational principle, intelligence, and fantasy is evident.

Key words: the psychology of creativity, creative abilities, creative personality, creative thinking, talent, improvisation, creativity.

Каплієнко-Ілюк Юлія Володимирівна, кандидат мистецтвознавства, доцент, докторант Одеської національної музичної академії ім. А. В. Нежданової

Психологічні передумови музичної творчості

Мета статті - проаналізувати психологічні основи творчого мислення як передумови музичної творчості. Методологія визначається працями психологічного спрямування, де приділяється увага психології творчості, проблемам музичного таланту та творчого мислення, енциклопедичними джерелами, у яких розкривається сутність поняття творчості, музикознавчими дослідженнями, присвяченими питанням творчого процесу та музичної діяльності. Наукова новизна полягає у науковому осмисленні передумов музичної творчості; у систематизації психологічних основ творчого процесу; у з'ясуванні засад творчого мислення. Висновки. Музична творчість - це складний процес художньо-творчого мислення, що передбачає створення нових духовно цінних творів. Психологічні передумови музичної творчості, такі як талант, майстерність, інтуїція, креативність, імпровізація, пов'язані, перш за все, з психічно-розумовим розвитком суб'єкта. Однак, важлива роль навчання, набуття навичок і досвіду, формування уяви та накопичення вражень, адже процес творчості пов'язаний з розумовими операціями над матеріалом за допомогою, насамперед, свідомих механізмів. В музичній творчості безперервно відбувається активна та безперервна кореляція між свідомим та несвідомим. Ці два типи мислення взаємодоповнюють свої дії, чергуючись у залежності від поставлених завдань перед композитором. Творчі завдання реалізуються за допомогою творчо-психологічних установок, серед яких, важлива роль емоцій, інтуїції, розуму, логіки, раціонального начала, інтелекту, франтазії.

(c) Kapliyenko-Iliuk Yu., 2020 
Ключові слова: психологія творчості, творчі здібності, творча особистість, творче мислення, талант, імпровізація, креативність.

Каплиенко-Илюк Юлия Владимировна, кандидат искусствоведения, доцент, докторант Одесской национальной музыкальной академии им. А. В. Неждановой

\section{Психологические предпосылки музыкального творчества}

Цель статьи - проанализировать психологические основы творческого мышления как предпосылки музыкального творчества. Методология определяется трудами психологического направления, где уделяется внимание психологии творчества, проблемам музыкального таланта и творческого мышления, энциклопедическими источниками, в которых раскрывается сущность понятия творчества, музыковедческими исследованиями, посвященными вопросам творческого процесса и музыкальной деятельности. Научная новизна заключается в научном осмыслении предпосылок музыкального творчества; в систематизации психологических основ творческого процесса; в выяснении основ творческого мышления. Выводы. Музыкальное творчество - это сложный процесс художественно-творческого мышления, предусматривает создание новых духовно ценных произведений. Психологические предпосылки музыкального творчества, такие как талант, мастерство, интуиция, креативность, импровизация, связанные, прежде всего, с психически-умственным развитием субъекта. Однако, важна роль обучения, приобретения навыков и опыта, формирование воображения и накопления впечатлений, ведь процесс творчества связан с умственными операциями над материалом с помощью, прежде всего, сознательных механизмов. В музыкальном творчестве непрерывно происходит активная и непрерывная корреляция между сознательным и бессознательным. Эти два типа мышления взаимодополняют свои действия, чередуясь в зависимости от поставленных задач перед композитором. Творческие задачи реализуются с помощью творческипсихологических установок, среди которых важная роль эмоций, интуиции, ума, логики, рационального начала, интеллекта, франтазии.

Ключевые слова: психология творчества, творческие способности, творческая личность, творческое мышление, талант, импровизация, креативность.

Relevance of research topic. Musical creativity associated with composer activity is a complex process of human activity, due, above all, to the psychological foundations of the essence of man. Creative abilities, talent, ability to improvise, to create music these are the qualities that are inherent to certain individuals and are distributed, unfortunately, not to everyone. Human society, scientists, scholars, philosophers, artists have always been interested in the secret of creativity. Therefore, studies devoted to the study of this problem, the definition of psychological foundations of creativity, in particular, musical, are both relevant and timely.

Analysis of recent research and publications. Problems of creative thinking, musical creativity, and the psychology of the creative process have repeatedly become the object of scientific research in the field of philosophy, aesthetics, psychology, musical pedagogy, and art studies. However, most of the research was made in the last century. Among the modern achievements are the works of M. Aranovsky, V. Petrushin, which reveal certain psychological aspects of musical creativity and peculiarities of creative thinking.

The purpose of the research is to analyze the psychological foundations of creative thinking as a prerequisite for musical creativity.

Basic presentation of the material. An important and special component of artistic thinking is creativity, which grows into a system of creative thinking and process. Psychology of creativity as a science arose at the turn of the $19^{\text {th }}$ and $20^{\text {th }}$ centuries. According to the encyclopedic definition, creativity is the activity of a person whose basis is the creation of new material or spiritual values in any field of endeavor, science, art, etc. Musical creation involves the creation of music, the type of artistic activity, whose preconditions are the natural talent, artistic skill, vocational education, life experience, social maturity, imagination, and inspiration $[9,505-506]$.

Creativity and its process are not always understandable, a great mystery is concealed here, which, as some scientists believe, even does not have to be solved. "The mystery of creativity! You can know the secret of counterpoint, learn the musical form, perfectly understand what forms the science of harmony, rhythm, but the secret of creativity is incomprehensible, it is beyond these rules" [8, 90]. Consequently, the system of creative thinking is multifaceted, with special patterns in structure and development, creating a musical form of the work; it becomes a part of another system - the artistic culture of an individual nation, nation or humanity as a whole. The artistic culture, in its turn, is a component of the metasystem of the sociohistorical life of mankind.

Speaking about creativity and mechanisms of the creative process, one undoubtedly presumes the presence of talent, natural gift, and abilities. "Talent, - as A. I. Mukha points out, - is the acuteness of perception, the richness, and capacity of derivative musical impressions, special knowledge, the persuasiveness of professional experience, combined with the sensitivity of comprehension of all the important and exciting in life; talent manifests itself in the generosity of inspiration, in precise ideological and emotional decisions, in the sense of artistic taste and measure, in the liberation of fantasy, and in the courage and fruitfulness of the innovative search" [5, 195].

M. Aranovsky writes about talent as follows: "Talent is one of the great mysteries of nature that can be compared with the cause of the origin of the universe or individual self. Talent is not subject to rational analysis, it evades any calculation methods that are inaccessible to the attack of consciousness. It reveals 
itself in the results, but the mechanisms of its work are hidden from us behind seven seals" [1, 117]. Thus, talent is a sphere of "musical unconscious" (according to M. Aranovsky), for which the bulk of musical values is acquired. Usually, musical thinking of a creative person is impossible without the process of learning, acquisition of knowledge, skills, and abilities, because one of the features of the human psyche is the ability to transfer and amass the experience of previous generations.

The branch of the "musical conscious" (M. Aranovsky) is extremely important in the process of creating polyphonic works, where without knowledge it is not possible to simply intuitively organize the creative process, in particular, to piece together a fugue (to piece together, not to create). Intuition is part of the unconscious process that underlies one of the most mysterious mechanisms of music creation which is improvisation. After all, intuition is seen as an instant illusion that is inherent in a few creative individuals, "as a mystical creative activity that provides the direct comprehension of truth as a gift of anticipation, foresight" [7, 12]. In the art of improvisation, the creative act is compressed to instant moment, fundamentally limited to the creation of a random, uncontrolled and unique variant. In the professional composer's work, in a certain connection with the process of improvisation, there is still a search, selection and awareness of the only best option, characterized by completeness, musical fixation and evaluation of even a spontaneously isolated version [see Günter Philipp. Klavierspiel; Philipp Günter. Erfahrungen].

Improvisation, from the psychological point of view, is related to the so-called anticipation, that is, a peculiar ability to act and make decisions with a certain time-spatial prediction. Anticipation in its various forms is a universal phenomenon of the human psyche inherent in various types of activities and associated with memory and thinking $[3,5]$. Memory is the main tool of anticipation; it recycles the information received and, by generalization, retains the most significant. "Thinking is primarily a prediction," notes B. F. Lomov and E. M. Surkov. Anticipation activates the forward "running ahead" in the brain the allows you to outstrip future events, using the experience gained in the past $[3,11]$. When characterizing the process of anticipation, researchers consider the maximum elimination of uncertainty and inaccuracy in the decisions taken as the most important factor: "Anticipation is not only a spatio-temporal advance but a certain degree of completeness and accuracy of prediction. The effect of anticipation is the result of maximizing the "deterministic part" of the act of solution acceptance and constant refinement of the "probable part" of the prediction" [3, 42]. So, the actual act of creative improvisation, one way or another, is connected with the unconscious process of creation. However, for the virtuoso composer who is able to improvise, anticipation is enough to implement it in its own creation and, possibly, to reproduce it or even write it down. Such a prediction for the composer may become not only the result of creative action but also an impetus, a push for the creative process. Thus, improvisation is not separated from the composition. According to many researchers, the composer or improviser creates a musical material from the finished blocks, manipulating them and making it like a mosaic. As S. Maltsev generalizes, "improvisation in any concrete historical form is always in one form or another based on the combination of some finite wealth of relatively stable elements ..." [4, 23].

In explaining the psychological mechanisms of solving the creative task of decisive importance in the development of events in the field of consciousness was the dependence on the sphere of the unconscious. It is here that the preservation of information, its classification and processing takes place, and produces ideas for solving problems in the conscious sphere. However, only the conscious part can complete the discovery.

Consequently, the creative process, in particular, musical creativity, is carried out as a result of mental operations on the material, sometimes with the help of conscious and sometimes unconscious mechanisms. In musical creativity there is a continuous and continuous correlation between the conscious and the unconscious. These two types of thinking complement each other and alternate depending on the tasks set before the composer.

The psychological mechanism of a creative act is characterized by a number of derivative concepts (according to A. I. Mukha): creative setting or inspiration is the psychological setting of the composer, stimulated by life experiences and personal will; creative task is an objective form of creative setting; creative impulses are reflection of life experiences transformed into personal psychological motivations; a set of creative motivations as a collection of natural data, training, knowledge, impressions, and creative skills, which serve as a condition for the performance of a creative act; zone of perception that ensures the receipt, expansion, and accumulation of various impressions; zone of control is a system of criteria for evaluation and principles for the selection of elements of the future work; memory zone is the branch of the psyche, which holds all the stock of impressions, motions, images, ideas, ideas, skills, etc.; reproductive zone that allows the composer to mentally or actually reproduce a set of phenomena previously perceived and stored in memory; zone of primary synthesis is the branch of subconscious and "superconscious" activity, where links, interactions, and interpenetration are established between elements-stimuli.

Until the middle of the $20^{\text {th }}$ century, creative abilities were associated in psychology with the level of intellectual development. However, in the research process, the lack of direct dependence on creative abilities on intelligence and acquired knowledge has been proven. That is, there is no correlation between the intelligence quotient and the ability to create something new.

The problem of creative and intellectual abilities has three main approaches: 
1. Creative abilities do not exist. The main value in the emergence of creative behavior is motivation, values, and personality traits. Creative abilities are insufficient conditions for human creative activity.

2. Lack of creative process as a specific form of mental activity. A high level of intelligence involves a high level of development of creative abilities and vice versa.

3. Creative abilities, creativity is a factor that does not depend on intelligence [2].

Creativity has become the subject of research since 1959 when a group of scientists led by J. Gilford studied this phenomenon with the help of factor analysis on the material of exact sciences. A number of experiments on the basis of art were conducted in parallel in the same year by W. Lawfield and K. Beyttel. As a result of the comparisons, the following criteria were identified:

1. The ability to see the problem.

2. Speed, the ability to see in the problem as many sides and connections as possible.

3. Flexibility as the ability to understand a new point of view or to abandon it.

4. Originality, avoiding templates.

5. Ability to rearrange ideas and relationships.

6. Ability to abstract or analyze.

7. The ability to concretize or synthesize.

8. A sense of harmony when organizing ideas.

The results of repeated studies of the phenomenon of creativity have proven that this is quite a complex phenomenon and, in general, is not subject to factor analysis. Creativity, whose basis is talent, creativity, intellectual ability, etc., is associated with the enormous amount of energy (nervous, mental, physical) aimed at the process of creation. Spiritual and physical stress, which is caused by the decision of a creative task, exceeds the ordinary possibilities of a person and entails a certain measure of fatigue, a feeling of devastation, even depression and apathy.

The subject of creativity is a creative individual who has certain features formulated by American psychologist K. Taylor: desire to always be at the top of their field of activity; self-reliance and independence of judgments, desire to go their own way; predisposition to risk; active attitude, curiosity, tireless search; dissatisfaction with the existing traditions and methods, desire to change the current state of things; nonstandard thinking; gift of communication; and talent of foresight [6, 74-75].

Consequently, the creative person has special features and creative data, representing the organic unity of the external and internal. A. I. Mukha formulates the prerequisites for full-fledged creative activity as follows:

1. Group of psychological prerequisites-characteristics of creativity: biological, generalpsychological, and musical-psychological natural data.

2. Group of ideological prerequisites-characteristics: the presence of social, philosophical, artistic, ethical ideals, ideas, views, and beliefs close to the author.

3. Group of technological prerequisites-characteristics: professional knowledge, craft skills, composer's practical experience.

4. Artistic and aesthetic prerequisites-characteristics: the figurative-associative sphere of composer's thinking, ability to perceive phenomena of the surrounding reality from the standpoint of musician-artist.

5. Cultural dynamic prerequisites-characteristics: the ability to understand and intuitive sense of internal, relatively independent logic and trends of development of healthy traditions of art [5, 140-141].

These conditions, reflecting the creative qualities of the artist, characterize his/her "creative personality", turning into a specific feature of the composer's creative style.

Conclusions. At the heart of musical creativity is the complex process of artistic and creative thinking, which involves the creation of new material and spiritual values. Prerequisites of musical creativity are talent, skill, intuition, creativity, improvisation, primarily related to the spiritual and mental development of the individual. At the same time, education, acquisition of skills and experience, the formation of imagination and accumulation of impressions are important, as the process of creativity is associated with mental operations on the material through, first of all, conscious mechanisms.

In the realization of the creative task, the important role of the fundamental ways of realizing the creative-psychological setting, namely: emotions, intuitions, reason, logic, rational principle, intelligence, fantasy. These manifestations of behavior associated with personality abilities, interact closely, mutually control and sometimes "counter-insure" each other.

\section{References}

1. Aranovskiy, M. (2012). Music, Thinking, Life. Articles, interviews, memoirs. N. A. Ryzhkova (Ed.). Moscow: Gosudarstvennyy institut iskusstvoznaniya [in Russian].

2. Druzhinin, V. N. (1995). Psychology of General Abilities. Moscow: Lanterna : Vita [in Russian]

3. Lomov, B. F. \& Surkov, Ye. N. (1980). Anticipation in the Structure of Activity. Moscow: Nauka [in Russian].

4. Maltsev, S. (1991). On the Psychology of Musical Improvisation. Moscow: Muzyka [in Russian].

5. Mukha, A. I. (1979). The Process of Compositional Creativity. Kyiv: Muzychna Ukrajina [in Ukrainian]

6. Petrushin, V. (2008). Musical Psychology: Textbook for Universities, (2nd ed.). Moscow: Akademicheskiy Proekt; Triksta [in Russian].

7. Ponomarev, Ya. A. (1960). Psychology of Creative Thinking. Moscow: Nauka [in Russian]. 
8. Shaginyan, M. S. (1968). Joseph Myslivechek ("Resurrection from the Dead"). (Issue 450 The Life of Wonderful People). Moscow: Molodaya gvardiya [in Russian].

9. Shteynpress, B. S. \& Yampolskiy, I. M. (1966). Encyclopedic Musical Dictionary. Moscow: Sovetskaya entsiklopediya [in Russian].

\title{
תimepamypa
}

1. Арановский М. Музыка, мышление, жизнь. Статьи, интервью, воспоминания / ред.-сост. Н. А. Рыжкова. Москва: Государственный институт искусствознания, 2012. 440 с.

2. Дружинин В.Н.Психология общих способностей. Москва: Лантерна : Вита, 1995. 150 с.

3. Ломов Б. Ф., Сурков Е. Н. Антиципация в структуре деятельности. Москва: Наука, 1980. 280 с.

4. Мальцев С. О психологии музыкальной импровизации. Москва: Музыка, 1991. 88 с.

5. Муха А. И. Процесс композиторского творчества. Киев: Музична Україна, 1979. 271 с.

6. Петрушин В. Музыкальная психология: Учебное пособие для вузов. 2-е изд. Москва: Академический Проект; Трикста, 2008. 400 с.

7. Пономарев Я. А. Психология творческого мышления. Москва: Наука,1960. 352 с.

8. Шагинян М. С. Йозеф Мысливечек ("Воскрешение из мертвых"). Москва: Молодая гвардия, 1968. 339 с.: (Жизнь замечательных людей, вып. 450).

9. Штейнпресс Б.С., Ямпольский И. М. Энциклопедический музыкальный словарь. Москва: Советская энциклопедия, 1966. 632 с.

Стаття надійшла до редакції 15.11.2019 р. Прийнято до публікації 13.12.2019 р.

УДК 75.03 (477.85)"19-20"

\author{
Міщенко Ірина Іванівна \\ кандидат мистецтвознавства, доцент, \\ докторант Національної академії \\ керівних кадрів культури і мистецтв \\ ORCID 0000-0002-3525-5885 \\ irynart@ukr.net
}

\section{ЖИВОПИС АРТЕМА ПРИСЯЖНЮКА: ВІД ТЕМАТИЧНОЇ КАРТИНИ ДО АБСТРАКТНОЇ КОМПОЗИЦІї}

\begin{abstract}
Мета статті: мистецтвознавчий аналіз доробку Артема Присяжнюка, творчість якого є показовою 3 точки зору зміни стилістики в українському мистецтві кінця XX - початку XXI ст.. Методологією дослідження $є$ історичний, біографічний та системний підходи. Використаний також мистецтвознавчий аналіз, методи порівняння та узагальнення. Наукова новизна полягає у введенні в науковий обіг відомостей про сучасне буковинське мистецтво та творчість окремих художників, аналізі стилістичних змін у малярстві регіону. Висновки. Дослідження цієї теми дає змогу об'єктивно підійти до мистецтвознавчої оцінки поступу буковинського живопису кінця XX перших десятиліть XXI ст. загалом та спадщини окремих майстрів. У доробку Артема Присяжнюка (1947-2017) наявні твори монументального мистецтва, гобелени, скульптурні та живописні роботи. Дослідження творчості художника від кінця 1980-их до 2010-их рр. дозволяє відстежити зміни у його малярстві - поступовий перехід від тематичних картин, робіт публіцистичного характеру до абстрактних композицій. Значними чинниками впливу на формування живописної манери митця стали увага до композиційної структури робіт, характерна для львівської художньої школи, та професійне заняття гобеленом (А. Присяжнюк за освітою був художником текстилю). Останнє визначило особливо важливу роль фактури поверхні у малярських творах цього автора. Якщо у роботах кінця 1980-их - початку 1990-их рр. найчастіше зустрічалися публіцистичні мотиви, обумовлені соціально-політичною ситуацією в Україні і зверненням до неоднозначних і складних періодів в історії держави, то згодом найбільшим зацікавленням митця стане відображення емоційних станів та сприйняття сучасних подій через асоціації, відтворені співвідношенням колірних плям та ритмом ліній, грою різноманітних фактур тощо.
\end{abstract}

Ключові слова: Артем Присяжнюк, гобелен, живопис, Чернівці, тематична картина, абстрактне мистецтво.

Мищенко Ирина Ивановна, кандидат искусствоведения, доцент, докторант Национальной академии руководящих кадров культуры и искусств

Живопись Артема Присяжнюка: от тематической картины к абстрактной композиции

Цель статьи: искусствоведческий анализ наследия Артема Присяжнюка, творчество которого является показательным с точки зрения изменения стилистики в украинском искусстве конца XX - начала XXI века. Методологией исследования являются исторический, биографический и системный подходы. Использован также искусствоведческий анализ, методы сравнения и обобщения. Научная новизна заключается во введении в научный оборот сведений о современном буковинском искусстве и творчестве отдельных художников, анализе стилистических изменений в живописи региона. Выводы. Исследование этой темы позволяет объективно подойти к искусствоведческой оценке развития буковинской живописи конца XX - первыX десятилетий XXI в. в целом и наследия отдельных мастеров, в частности. Среди работ Артема Присяжнюка (1947-2017) есть произведения монументального искусства, гобелены, скульптурные и живописные работы. Исследование творчества художника с конца 1980-х до 2010-х гг. позволяет отследить изменения в его живописи - постепенный переход от

() Міщенко І. І., 2020 